\title{
RUSSIAN POLITICAL DISCOURSE IN THE FOCUS OF LINGUISTIC ECOLOGY ${ }^{1}$
}

\author{
Natalya A. Bozhenkova \\ Pushkin State Russian Language Institute, Moscow, Russia \\ Pavel A. Katyshev \\ Pushkin State Russian Language Institute, Moscow, Russia \\ Svetlana V. Ionova \\ Pushkin State Russian Language Institute, Moscow, Russia \\ Elmira M. Afanasyeva \\ Pushkin State Russian Language Institute, Moscow, Russia \\ Levon N. Saakyan \\ Pushkin State Russian Language Institute, Moscow, Russia
}

\begin{abstract}
The article provides an overview of typological mechanisms in the arrangement of communicative practices in modern political discourse and methods of verbal explication of its axiological and symbolic constituents, $\underset{\sim}{\sim}$ determining mental universals in individual/collective consciousness. The study provides a systematic characterization of linguistic and social-and-cultural dominants in political interaction. Verbal indicators of social asymmetry are identified. The description of the language of political discourse aspectual data are summarized. A multilevel analysis of the component structure of political interactions is carried out. The genre specifics of legitimate and illegitimate communicative acts is taken into consideration. The combination of the methods applied in discourse analysis, such as linguistic cognitive projection, linguistic-and-cultural interpretation and functional-and-pragmatic examination of text units, enabled the researchers to identify and qualify linguo-semiotic elements of political practices. Hence, an ecolinguistic typology of basic linguistic components of political communication acts characterized by various legitimacy degrees has been carried out. The study revealed a possibility to single out a specific communicative range in Russian political discourse, in the framework of which linguistic and cultural resources of ideologically charged discursive practices would be actualized and the area of possible communication risks would be significantly expanded.
\end{abstract}

Key words: political discourse, ecolinguistics, legitimate political practices, illegitimate political practices, linguistic-and-cultural dominants, verbal indicators, communicative risks.

Citation. Bozhenkova N.A., Katyshev P.A., Ionova S.V., Afanasyeva E.M., Saakyan L.N. Russian Political Discourse in the Focus of Linguistic Ecology. Vestnik Volgogradskogo gosudarstvennogo universiteta. Seriya 2. Yazykoznanie [Science Journal of Volgograd State University. Linguistics], 2019, vol. 18, no. 3, pp. 76-92. (in Russian). DOI: https://doi.org/10.15688/jvolsu2.2019.3.6

\section{РУССКИЙ ПОЛИТИЧЕСКИЙ ДИСКУРС В ФОКУСЕ ЛИНГВОЭКОЛОГИИ ${ }^{1}$}

\author{
Наталья Александровна Боженкова
}

Государственный институт русского языка им. А.С. Пушкина, г. Москва, Россия 


\section{Павел Алексеевич Катышев}

Государственный институт русского языка им. А.С. Пушкина, г. Москва, Россия

\section{Светлана Валентиновна Ионова}

Государственный институт русского языка им. А.С. Пушкина, г. Москва, Россия

\section{Эльмира Маратовна Афанасьева}

Государственный институт русского языка им. А.С. Пушкина, г. Москва, Россия

\section{Левон Николаевич Саакян}

Государственный институт русского языка им. А.С. Пушкина, г. Москва, Россия

Аннотация. В статье рассматриваются типологические механизмы организации коммуникативных практик современного политического дискурса и способы языковой экспликации его аксиологических и символических конституентов, детерминирующих ментальные универсалии индивидуального / коллективного сознания. Представленная статья является результатом совместной работы авторов под руководством Н.А. Боженковой, предложившей методологическую концепцию исследования, направленную на системную характеризацию лингво- и социокультурных доминант политического взаимодействия и установление вербальных показателей социальной асимметрии. На основе этой концепции обобщены аспектные данные описания языка политического дискурса. Позиция авторского коллектива базируется на многоуровневом анализе компонентной структуры политических интеракций с учетом жанровой специфики легитимных (Э.А. Афанасьева) и нелегитимных (П.А. Катышев) коммуникативных актов. Совмещение методов дискурсанализа, лингвокогнитивной проекции, лингвокультурологических истолкований и функционально-прагматического рассмотрения текстовых единиц дало возможность выявить и квалифицировать лингвосемиотические элементы политических практик (П.А. Катышев, Л.Н. Саакян) и на этом основании осуществить эколингвистическую типологизацию (С.В. Ионова) базисных языковых составляющих актов политического общения, различных по степени легитимности. Результаты проведенного исследования свидетельствуют о возможности выделения особого коммуникативного регистра русскоязычного политического дискурса, в котором актуализируются лингвокультурные ресурсы различных дискурсивных практик и одновременно существенно расширяется зона возможных коммуникативных рисков.

Ключевые слова: политический дискурс, эколингвистика, легитимные политические практики, нелегитимные политические практики, лингвокультурные доминанты, речевые маркеры, коммуникативные риски.

Цитирование. Боженкова Н. А., Катышев П. А., Ионова С. В., Афанасьева Э. М., Саакян Л. Н. Русский политический дискурс в фокусе лингвоэкологии // Вестник Волгоградского государственного университета. Серия 2, Языкознание. -2019. - Т. 18, № 3. - C. 76-92. - DOI: https://doi.org/10.15688/jvolsu2.2019.3.6

\section{Введение}

Современные геополитические условия, отличительной чертой которых являются интегративно-миграционные процессы, актуализируют многочисленные проблемы семиотико-семасиологической организации социально-коммуникативной системы - от установления принципов образования ее аксиологических компонентов в условиях поликультурности и полилингвизма до описания норм речевого поведения, характерных для данного универсума.

В этой связи оказывается закономерным появление новой, образовавшейся на стыке экологической и языковедческой проблемати- ки области исследований - эколингвистики, предмет которой детерминируется дихотомией «объект - среда» и может быть, на наш взгляд, экстраполирован на любые социальные взаимоотношения. Соответственно, в рамках эколингвистики выделяются два подхода к изучению социокоммуникативных проблем рассмотрение их через призму экологии язы-

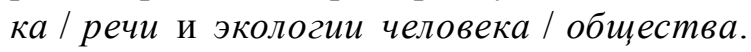
Сочетание указанных подходов лежит в основе проводимого нами анализа материала и позволяет определить эколингвистику как синергетическую область языкознания, объектом которой являются: 1) состояние языка как семиотической системы, обусловленное влиянием на языковое сознание социума и его ре- 
чевую культуру различных экстралингвистических факторов; 2) способы «защиты» языка как компонента коммуникативной интеракции от негативных влияний и одновременно методы и пути его сохранения, обогащения и развития ${ }^{2}$. Подчеркнем, что причины формирования эколингвистики и решаемые ею проблемы имеют универсальный характер (актуальны для всех языковых сообществ), поскольку ее аксиологической доминантой является «сохранение языковой идентичности этноса и на этой основе нравственного здоровья общества и национальной безопасности государства» [Бернацкая, 2014, с. 28].

Корпус лингвоэкологических проблем русскоязычного пространства, констатируемых учеными, объемен и динамичен, поскольку сама лингвоэкологическая ситуация - явление диффузное. Вместе с тем, несмотря на отсутствие единого метаязыкового аппарата, явно выделяются следующие:

- лексико-семантические утраты (в первую очередь архаизация книжной лексики и «выпадение» из языкового сознания носителей значительного количества паремиологических единиц) и одновременное восстановление историзмов (слов и фразеологизмов) в качестве функционирующих языковых единиц (с изменением / расширением их семасиологического компонента);

- жаргонизация ${ }^{3}$ / вульгаризация речи (особенно медийной) и лавинообразное «внедрение» иноязычных вербальных знаков (как правило, англицизмов / американизмов), являющихся варваризмами;

- «размывание» этико-эстетических норм речевого общения, обусловленное определенной утратой ценностного компонента русской (и не только) классической литературы и сосуществованием во множестве современных текстов диалектически несоотносимых явлений (например, инвективной / обсценной лексики и общего пафоса высказывания);

- «переосмысление» / дискредитация вербальных знаков, являющихся национальными символами (государственной власти, исторических побед, этнокультурной причастности и др.);

- манипулятивное использование социально-культурных терминов и коннотативная амбивалентность трансляции идеологически маркированных единиц, определяемые не столько принципиальными политическими установками коммуникантов, сколько латентными целями управления аудиторией;

- конструирование, воспроизводство и зачастую монетизация дискурсивных практик, оказывающих вредоносное воздействие на мировоззрение, ценностные предпочтения и поведение социума, в особенности на подрастающее поколение (вовлекающие дискурсивные практики радикальных сообществ; дискурсы, связанные с пропагандой суицида, растлением малолетних и т. д.).

Очевидно, что обозначенный круг эколингвистических проблем охватывает все сферы жизнедеятельности человека, но наиболее заметными они оказываются в пространстве политической коммуникации уже на том основании, что, будучи включенным в этнокультурное поле любого социума, политическое общение эксплицирует многоярусную систему идей, целей и интересов государства в целом.

Политическая жизнь языка и природа политического языка, несмотря на значительное число работ в этой области, до сегодняшнего дня остаются непознанными. Какими знаковыми компонентами «оснащается» современный политический язык, как трансформируется языковое сознание его носителей и возможно ли сегодня говорить об особом коммуникативном регистре русскоязычного политического дискурса XXI века? В аспекте эколингвистических взглядов возникает необходимость описания сущности современного политического дискурса, выявления его категориальных единиц и формулирования ряда лингвопрагматических закономерностей, которые могут быть экстраполированы на решение экологических задач языка в целом.

\section{Материал и методы}

Основным методологическим вектором в описании политической коммуникации, опосредованной различными социокультурными условиями, был выбран дискурс-анализ, выявляющий, как создаются и поддерживаются идеологически маркированные объекты, включенные в универсум, и как они актуализируются в хронотопическом аспекте. Вери- 
фикация методологической концепции исследования позволила осуществить сопоставительный анализ лингвосемиотических доминант легитимных / нелегитимных политических практик и провести эколингвистическую типологизацию базовых конституентов актов политического общения, различных по степени легитимности.

Материалом исследования легитимных политических дискурсивных практик послужили скрипты выступлений (имеющих тематическую и жанровую общность) представителей российской политической элиты, в связи с чем особое внимание отводилось опубликованным в официальных источниках пресс-релизам, текстам брифингов, комментариев и интервью, эксплицирующим сущностное единство (при неоднозначности идеологических позиций) лингвосемиотических конституентов политического пространства (более 1000 текстовых единиц). Изучение нелегитимных политических дискурсивных практик проводилось на материале корпуса текстов, собранных на этапе досудебного расследования случаев вовлечения граждан в деятельность террористических организаций, функционирование которых запрещено на территории Российской Федерации решением Верховного суда РФ от 14 февраля 2003 года. В корпус включено 43 записи устных бесед продолжительностью 74 часа и объемом в 405 тыс. словоупотреблений.

Целостность предлагаемой концепции изучения коммуникативного взаимодействия, ориентированной не только на национальноценностные категории социума, но и на напряженные точки институционального общения, относительно которых осуществляется манипуляция общественным сознанием, и репрезентативность материала исследования обеспечивают, по мнению авторов, достоверность выводов проведенного сопоставительно-типологического анализа.

\section{Результаты и обсуждение}

Политическое взаимодействие как социально-коммуникативная сфера оказалось в фокусе российского научного интереса в последней трети XX в., когда постперестроечные инновации в русском языке приобрели харак- тер этнокультурных маркеров. Категоризация учеными дефиниции политический дискурс, как и в ситуации с дискурсом в целом, привела к появлению внушительного списка определений: одни исследователи (А.П. Чудинов, М.М. Лазар и др.) используют термин «политический дискурс» как данный a priori; другие (А.Н. Баранов, Е.И. Шейгал, Т.А. ван Дейк, Р. Водак и др.) считают его синонимичным номинациям политическая коммуникация, политический язык, язык политики; третьи (М.Б. Паршин, Ю.С. Степанов и др.) отказываются признать за ним строго лингвистическое значение. Расхождение взглядов ученых объясняется тем, что политический дискурс чрезвычайно неоднородный объект исследования, поскольку «лежит на пересечении разных дисциплин: политологии, социальной психологии, лингвистики - и связан с анализом формы, задач и содержания дискурса, употребляемого в определенных (“политических") ситуациях» [Демьянков, 2001, с. 118].

С точки зрения авторов статьи, политический дискурс есть речевая деятельность субъектов в сферах политического институционального общения, детерминированная определенной социально-ролевой иерархией и объективированная в виде совокупности текстовых единиц политической направленности во всем их жанровом и функциональном многообразии. Будучи разновидностью дискурса институционального, политический дискурс характеризуется совокупностью конститутивных признаков (системностью, функциональной завершенностью, отсутствием строгих структурных ограничений, коммуникативной определенностью) и реализует те же функции, что и дискурс в целом, - информативную, делимитативную, аргументативную, групповыделительную и персуазивную. Специфическими принято считать агональную функцию, функцию социальной идентификации, функцию контроля, имманентно включающую манипуляцию общественным сознанием, интерпретационную функцию, способствующую созданию «языковой реальности» поля политики [Паршина, 2004]. В этот перечень включим и функции, констатированные Д. Грейбер: определение повестки дня (agenda setting), распространение информации (information dissemination), проекция в будущее и прошлое (projection to 
future and past) [Graber, 1981, p. 198]. Последние характеристики, актуализируясь в рамках политической коммуникации, и определяют базисный признак политического дискурса - его использование в качестве инструмента овладения властью, ее перераспределения и сохранения. Так, распространение информации о состоянии дел в политическом сообществе - важнейшая функция политических интеракций по отношению к гражданскому обществу, поскольку его члены обычно не имеют собственного опыта политического участия и их знания складываются на основе предлагаемых им «вербальных картинок». Такие сообщения имеют разные формы (описания, мнения, выводы) и реализуются в различных жанрах (официальном заявлении, послании законодательному органу, пресс-конференции, интервью и др.). Наряду с эксплицитной информацией текстовые единицы содержат имплицитно-коннотативные элементы (эмотивно окрашенные ключевые слова, репрезентирующие политические ориентации и ценности; патриотические символы и пр.), при этом значимыми оказываются хронотопические характеристики вербального акта, его «подчиненность» историко-культурным и аксиологическим факторам, система паралингвистических компонентов. Соответственно, политический дискурс «означивает» все конституенты социального поля: они или составляют собственно предмет общения (референциальный аспект), или становятся элементами прагматического контекста, в том числе и прагматическими пресуппозициями.

Особую картину политического мира определяют дифференциальные характеристики политического дискурса: специфическая институциональность, ритуальность и смысловая неопределенность, подкрепляемая неразрывной связью политических текстов с экстралингвистическими компонентами коммуникативной ситуации, в которой они были созданы, и одновременно с системой когнитивных установок адресанта. В этой связи встает вопрос о специфичности языкового обрамления политических дискурсивных практик и наличии самостоятельной системы профессионально ориентированных знаков - вербальных / невербальных / «семасиологически скрытых» (термин наш). Многие ученые (в отличие, например, от В.З. Демьянкова) отказывают системе политических языковых знаков в уникальности, подчеркивая, что своеобразные черты политического дискурса не всегда поддаются процедуре идентификации и обычно «не выходят за рамки соответствующих идиоэтнических языков» [Паршин, 2001, с. 193].

Внешняя «неспецифичность» политической коммуникации объясняется ее явной ориентацией на массового адресата: медиаресурсы становятся не только средой и средством ее существования, но и выступают как субъекты политической деятельности. Соответственно, политический дискурс XXI в. включает в состав участников новые группы носителей языка и приобретает новые формы, позволяющие актуализировать и транслировать даже такие виды политической деятельности, которые ранее не получали легитимных форм проявления.

В то же время основное качество политического дискурса - агональный характер, оставаясь его семиотической константой, составляет тот признак, по которому «он может быть отграничен от близких коммуникативных явлений» [Шейгал, 2000, с. 120]. Открытая соревновательность в межличностном / институциональном / кросс-культурном политическом взаимодействии детерминирует эколингвистическую специфику политического дискурса: усиливается конфликтогенность как результат выраженного через язык столкновения взаимодействующих субъектов, реализуются дезинтегративные коммуникативные стратегии, наблюдается использование инвектогенных знаков и др. Большая часть агональных тактик политического дискурса является его коммуникативной нормой, предельные же формы коммуникации в сфере политики - осознаваемые партиципантами установки на противостояние, деструктивность, разрушение достигнутого согласия и сотрудничества (см., например: [Юрислингвистика, 2006]) - предполагают, с нашей точки зрения, необходимость введения эколингвистического контроля.

Нельзя не учитывать и тот факт, что новые технологии генерируют новые средства, методы и жанры трансляции информации; это ведет к появлению новых моно- и полисемио- 
тических систем коммуникации и вносит коррективы в политическое общение: расширяются его тематические границы, изменяются дискурсивные параметры и способы языковой экспликации (форумы, социальные сети, блог политика и др.). Дисплейный текст как форма сетевых медиа обладает особыми дифференциальными признаками: поликодовостью (мультимедийностью), нелинейностью (разветвленностью и отсутствием начала / конца), интерактивностью (непосредственной связью с адресатом и обратным воздействием на структуру текста). Это напрямую влияет как на макроструктуру политического дискурса, так и на его языковые компоненты: увеличиваются объем и плотность дискурса; проявляется неоднозначность и «разнобой» употребляемых единиц ${ }^{4}$; смысл слова выхолащивается до пустой оболочки, которую можно наполнить любым, вплоть до противоположного, содержанием. В результате политическая коммуникация характеризуется энтропией, адекватность восприятия текста существенно снижается, обусловливая тем самым активизацию эколингвистических проблем, а поддерживаемые глобальной сетью «токсичные» коммуникативные практики оказывают значительное влияние на когнитивно-психологическую организацию и конкретной личности, и аудитории в целом.

Самым сложным в аспекте эколингвистики оказывается видоизменение функциональной нагрузки политической дискурсивной практики: к трем основным параметрам (информирование, манипуляция и контроль) добавляется четвертый, свойственный ранее лишь СМИ, - развлечение аудитории. Это неслучайно: при построении диалогического взаимодействия в политической среде (как легитимной, так и нелегитимной) значимость вербальных и невербальных средств, снимающих «напряженность контекста», многократно увеличивается - особая институциональность нередко детерминирует невозможность эксплицитного маркирования идеологем, что замещается включением широкого спектра прецедентных единиц и своеобразных коммуникативных приемов ${ }^{5}$. Таким образом, можно констатировать следующие важнейшие характеристики политического дискурса: метафоричность, эвфемистичность, лозунговость (с явной демонстрацией дихотомии «плохо хорошо», «свой - чужой»), утверждение «абсолютной истины» и одновременно иррациональность, которая опирается на традиции, ритуалы и неопределенность денотатов.

Язык политики сегодня инкорпорируется в бытовое и бытийное общение самых широких гражданских масс: признаки политического обнаруживаются и в так называемой культуре повседневности, и в практиках вовлечения в деятельность нелегальных сообществ. В этой связи для описания поля экологических проблем в языке российской политики представляется корректным разделить дискурсивные практики в соответствии с антиномией «легитимность / нелегитимность» и охарактеризовать «болевые места» коммуникативного поведения субъектов политического поля в ракурсе эколингвистической парадигмы.

\section{Легитимные политические практики} в аспекте эколингвистических проблем

Легитимные политические дискурсивные практики, являясь «ареной» выражения идеологических постулатов определенных социальных элит и одновременно платформой формирования общественного мнения по различным позициям, имеют многочисленные способы экспликации. В политических науках легитимность рассматривается как «качественная характеристика властных отношений, связанная с поддержанием убежденности граждан в том, что существующие политические институты и отношения соответствуют или должны соответствовать данному обществу и ценностно-нормативной динамике эволюции политических коммуникаций и публичной сферы» [Завершинский, 2016, с. 8]. При этом подчеркивается, что изучение властных коммуникаций неизбежно сводится к анализу символических структур политической власти и/или форм, методов, стратегий, тактик ведения политической коммуникации. Исследования лингвистов позволяют зафиксировать речевые особенности интеракции «власть - общество», определить (бес)перспективность их существования в условиях развития современного общества, тем самым обеспечить успешность легитимации принимаемых политических решений. 
В этой связи представляется корректным относить к легитимным политическим практикам те дискурсивные акты, в которых хотя бы одна из трех его составляющих субъект, адресат, содержание речевого произведения - принадлежит сфере политики. При таком - полевом (в терминологии Е.И. Шейгал) - подходе в центре оказываются «первичные» жанры (программные документы, официальные речи, выступления государственных лиц и др.), а на периферии находятся жанры вторичные, или конвергентные, сочетающие в себе элементы политического и иных видов дискурса (аналитические статьи, комментарии политических выступлений, письма в редакцию, пародии и т. д.). Однако при более детальном анализе конститутивных признаков трех перечисленных составляющих оказывается недостаточно: субъект и адресат, будучи политическими фигурами, могут вести, например, сугубо бытовой диалог. Соответственно, к названным элементам, с нашей точки зрения, необходимо добавить цель и перлокутивный эффект речевого акта, поскольку именно эти составляющие и позволяют идентифицировать коммуникацию как легитимную политическую практику. Кроме того, без их учета невозможно говорить об интеракционной модели коммуникации.

В условиях легитимной политической практики целеполагание и перлокутивный эффект должны (в идеале) совпадать, поскольку достижение, «семиотическое закрепление», трансляция ценностно-прагматического опыта (цель) и осмысленная ретрансляция аудиторией определенных аксиологических доминант (перлокутивный эффект) только в совокупности обеспечивают важнейшую компоненту антиномии «власть - общество» - нормативную заданность общественных отношений и социальную принудительность. При этом отметим дихотомичность соотношения категорий: с одной стороны, политический дискурс продуцирует и эксплицирует стандарты статусно-ролевого поведения, закрепляет бинарные отношения «норма / ненорма», «допустимое / недопустимое», «благо / зло» и т. п., выражающиеся в моральных императивах, кодексах поведения, правовых актах и др.; с другой - социальный институт политики «производит» и трансли- рует новые дискурсы (в форме идей, принципов, образов и иных символических фигур), которые задают «фокусные центры нашего видения и осмысления реальности» [Русакова, Русаков, 2008, с. 194].

Особую актуальность в данном ракурсе приобретает словарь политической действительности - своего рода «концептуарий социально значимых смыслов (кодов), символов, понятий и способов их представления» [Карасик, 2007, с. 268]. Его можно считать пер$\boldsymbol{b \boldsymbol { b } м}$ признаком, обнаруживающим специфику легитимных политических практик. Современная политическая жизнь маркируется преимущественно отрицательно заряженными лексемами: санкции, кибератаки, коррупция, разоблачение, провокачия, разрыв договора о... , раскольничья иерковь, угрозы, изоляиия России, удар по России, «смерть» Скрипаля, шпиль, начистские лозунги, террористические атаки, вмешательство в выборы, заговор, импичмент и др. ${ }^{6}$, в результате текстовые единицы, формирующие коммуникативно-идеологическую среду современного человека, приобретают отчетливую инвективную окрашенность.

Анализ частотности употребления единиц русского языка одновременно демонстрирует, что на периферию русского лексикона сместился значительный пласт слов, эксплицирующих важнейшие понятия русской культуры: сострадание, жалость, милосердие, совесть, стылдивость, добродетель, человеческое достоинство, справедливость, Родина, патриотизм. Форма вербального знака известна носителям языка, но диапазон функционирования уменьшается, употребление автоматизируется, а «содержание часто клишируется, превращаясь в штамп, и подвергается процессу энантиосемизации» [Ионова, Шаховский, 2012, с. 142]. По данным социолингвистики, кривая активности ключевого слова русского политического дискурса Родина / родина ${ }^{7}$, с 70-х гг. идет на спад (пик 30-60-е гг.), лишь с 2014 г. отмечается небольшой подъем. Слово патриотизм нередко наполняется противоположным содержанием: старая идеология; последнее прибежище негодяев; то же, что экстремизм и др. Показательно в этом плане выступление радиоведущей К. Лариной: 
Сегодня на «Дожде» я пыталась сказать, что всем самым чудовищным в человеке мы обязаны патриотизму. Патриотизм разрушителен, он ничего не создает, кроме трескотни, вранья, лицемерия. Патриотизм не совместим со свободой, он убивает свободу мысли, свободу творчества, свободу самореализации... Патриотизм сам по себе является религией вчерашнего дня, религией мертвых (Ларина К. Блог «Эхо Москвы», 03.02.2014).

Нельзя не отметить вместе с тем, что сегодня в политическом дискурсе наблюдается постепенный возврат традиционной семантики слова:

В чувстве патриотизма присутствуют различные составляющие, всех не перечислишь, поэтому выделим лишь главные его векторы. Это любовь к своей стране. Это уважение, а в определенных обстоятельствах и любовь, к своему государству. Это любовь к своему народу (В.В. Путин, https:// www.putin-today.ru/archives/20531);

Коммуникативная активизация таких идеологем, как Родина, патриотизм, национальная идея, героизм, спасение, зашита, объединение, не только свидетельствует о новом явлении в легитимных дискурсивных практиках - «эстетизации политики», но и, бесспорно, демонстрирует высокую ценностную составляющую данных понятий, определяющую их место в официальной политической информации.

Второй особенностью легитимных политических практик можно считать появление новых способов «депозитивации» общественного сознания, наиболее значимые из которых: 1) образование лексических композитов-оксюморонов (исчадие добра, ужас восторга, любовь-ненависть, достижение провала / неудачи и т. п.), вносящих в положительное понятийное поле отрицательный компонент; 2) включение языковых единиц, характеризующихся «размытой универсальностью» - минимальным / нулевым содержанием (прогресс, общественное мнение, путь созидания, истинная справедливость и др.); 3) специфическая эвфемизация, превращающаяся на уровне адресата в дисфемию (наведение конституционного порядка, вежливые люди, введение демократических принципов, наши западные партнеры и др.). Совокупность таких вербальных знаков, получающих метафорическое преломление в социальнокоммуникативной реальности, не только порождает устойчивые коннотативные негативы, но и организует направленную «информационную вертикаль», которая транслирует заранее предложенные темы и формирует общественное мнение в параметрах односторонней коммуникации. Неслучайно происходящее сегодня в медийном политическом поле уже окрестили «войной формулировок»: от того, как будет названа активная часть населения - гражданским обществом, протестным электоратом или ресурсом правящего режима, - зависит, как будет выстраиваться публичная политика. В этой связи существенно возрастает роль фразеологизированных публицистических стандартов, социально-типичных оценочных номинаций, прецедентных феноменов, привлекаемых в поле интерпретации и составляющих единое для коммуникантов «знание о мире». Например, в диалоге С. Минаева и И. Ружейникова с А. Хинштейном (радио «Маяк», 19.10.2010), содержанием которого была «горячая новость» - дело о червяке в тарелке губернатора Тверской области Д. Зеленина, - доминантным центром становится гротескное представление международного престижа России в (нано)червяках и чиновников в образе червяков, вылезающих изо всех дыр. В сообщении корреспондента «с места событий» (сюжет о грузинско-российском шпионском скандале, радио «Эхо Москвы», 05.11.2010) номинации заговор и ипионы с первых фраз формируют оценочное поле, а тематическое выражение шпионский скандал вводит фрейм 'вербовка - внедрение - шифровка - секретная информация связной - секретная операция - разоблачение - доказательства - предание гласности', подкрепляемый последующими сообщениями блока. С доказательствами связывается документальный фильм (ср.: документ 'свидетельство, служащее доказательством'), однако лексемы фильм и ипион актуализируют в сознании адресата представление о ипионском фильме, позволяя рассматривать референтный эпизод как часть некоего сценария и задаваться вопросом о реальности / театральности события. Постоянные «сказуемые» легитимных политических практик, маркирующие их переменные «подлежащие», 
метафорически транслируют идеологические константы и стереотипы, которые осознанно / неосознанно закладываются в социуме и ментальном поле этноса.

Можно констатировать, что вся риторика русскоязычного политического дискурса последнего времени направлена на «переформатирование» субъектности, идеологии и истории в целом: с одной стороны, создаются новые (или актуализируются старые) символические атрибуты (ср.: Kpым наш! vs. Партия жуликов и воров!), расширяется спектр прецедентных текстов и имен исторических деятелей (Георгиевская ленточка, Александр III), с другой - многочисленные лингвосемиотические конституенты (лозунги, слоганы, эмблемы, награды) дискредитируются и даже упраздняются в результате функционирования в политическом поле значительного числа публицистических, кинематографических и иных текстов с односторонними отрицательно-оценочными характеристиками данных символов. Приведем в связи с этим слова Ю.М. Лотмана о том, что «символ никогда не принадлежит какому-либо одному синхронному срезу культуры - он всегда пронзает этот срез по вертикали, приходя из прошлого и уходя в будущее» [Лотман, 2010, c. 185]. Соответственно, устранение символа из сознания социума видоизменяет доминантные смыслы, вырабатываемые и закрепляемые в пространстве языка, и порождает новый образ мира.

Tретьим специфическим признаком легитимных политических практик следует считать их имманентную манипулятивную направленность. В политической дискуссии люди, как правило, пытаются «уйти от ответа» на неприятные вопросы, скрыть нежелательные факты, при этом оказать воздействие на собеседника и «навязать» свое мнение. Однако и сам язык, как отмечает Т.М. Николаева, «располагает достаточным для этого набором средств - диалого-композиционных, синтаксических, собственно грамматических. Иначе говоря, язык обладает свойствами самоманипулирования» [Николаева, 1990, с. 225]. Действенными приемами, позволяющими вариативно интерпретировать действительность, в русском языке являются: номинализация (замена существительным прилагательного или глагола, ср.: Полищия жестоко расправилась с демонстрантами - Расправа с демонстрантами; поступать подло - подльй поступок - подлец); «языковая демагогия» (непрямое воздействие на реципиента, при котором субъективное утверждение, или ассерция, маскируется под суждение, воспринимающееся как общеизвестный факт, или пресуппозицию, что обычно маркируется конструкциями Как Bbl все знаете; Как известно; Общеизвестный факт и др.); персеверация (многократное настойчивое повторение $^{8}$, воздействующее и на языковое сознание, и на подсознание адресата информационного сообщения).

В качестве иллюстрации последнего приема приведем пример политической «игры с культурным кодом». 10 июня 2017 г. в Киеве на мероприятии по случаю введения безвизового режима Украины с Евросоюзом президент Украины П.А. Порошенко процитировал фрагмент стихотворения М.Ю. Лермонтова «Прощай, немытая Россия». Это выступление транслировалось в СМИ, попало в социальные сети, «прошло через сито» многочисленных журналистских комментариев. Таким образом, лермонтовский текст стал не только элементом речи политика, но и вошел в масскультурный контекст. Вслед за «выпадом» П.А. Порошенко в адрес России, в медиапространстве 1011 июня 2017 г. активно обсуждалась ситуация «культурного поединка» двух президентов. С одной стороны, в российских СМИ преобладал акцент на «поэтической дуэли» глав государств, о чем свидетельствуют заголовки публикаций:

Путин объяснил Порошенко смысл стихотворения про «немытую Россию» (НTB, https:// www.ntv.ru/novosti/1820544/);

Путин ответил на слова Порошенко о «немытой России» цитатой из Шевченко (ИНТЕРФАКС, https://www.interfax.ru/russia/566737).

С другой стороны, в российских СМИ был восстановлен ретроспективный контекст толкование президентом РФ стихотворения М.Ю. Лермонтова во время встречи с победителями Всероссийского конкурса «Учитель года $-2016 »$. Приведем цитату выступления В.В. Путина: 
Или «Прощай, немытая Россия». Казалось бы, такая вещь, грубоватая по отношению к стране: «Страна рабов, страна господ, / И вы, мундиры голубые, / И ты, им преданный народ». Но те, кто хочет увидеть этот негатив, на этом останавливаются, а там есть второе четверостишье: «Быть может, за стеной Кавказа / Укроюсь от твоих пашей, / От их всевидящего глаза, / От их всеслышащих ушей». Это написано когда? По-моему, в 1841 году. А в связи с чем? Он ехал на Кавказ. Он же был офицер и воевал за интересы Отечества. С одной стороны, он не приемлет вот этого официоза, наушничества и всяких слежек и так далее, с другой стороны, он готов жизнь отдать за интересы страны и Родины. Он был чрезвычайно храбрым человеком. И вторую часть стараются часто не замечать (Президент России, http:// www.kremlin.ru/events/president/news/53031/videos).

На волне поэтического поединка двух президентов в интернет-пространстве появляется передача Е. Яковлева «"Прощай, немытая Россия" - фейк?» (авторский цикл «Цифровые истории»), в которой авторство М.Ю. Лермонтова ставится под сомнение и выдвигается гипотеза о том, что стихотворение написал польский поэт Т.Л. Заблоцкий (https://www. youtube.com/watch? $\mathrm{v}=17 \mathrm{nx}$ CQmqWc). Тем самым политические баталии переводятся в сферу филологических дискуссий, а художественный текст в ситуации политического противоборства становится и аргументом противостояния, и особого рода «политическим громоотводом».

Произведение М.Ю. Лермонтова в речи П.А. Порошенко выполняет роль авторитетной ссылки: вырванный из контекста начальный стих - идеологический символ разрыва отношений Украины с Россией. В.В. Путин в свою очередь дает историко-биографический комментарий текста с учетом его эстетической целостности. Очевидно, что легитимный политический дискурс становится «многослойным»: в него «вплетается» дискурс художественных практик, «провоцируя» толкование реальных фактов в соотнесении с литературными произведениями и оказываясь базисом метафоризации политического факта как такового.

Четвертой характеристикой легитимных политических практик, особым образом актуализирующей эколингвистические проблемы, следует считать институциональную реверсию. Несмотря на расширение возмож- ностей общественного участия в социальных интеракциях, формы коммуникативного взаимодействия общества и власти конструируются, как правило, в соответствии со стратегией «сверху - вниз». В результате вырабатываются специальные речевые клише, закрепляются особые языковые знаки, воспринимающиеся субъектами политического поля как соответствующие дискурсивным задачам формулы регулирования поведения членов сообщества, при этом категоричность императива нивелируется лояльным отношением со стороны гражданского общества: проявления властной коммуникации часто считаются оправданными, поскольку в таких случаях демонстрируются позитивные ценности и образцы поведения (жизнь, порядок, толерантность, законность, эффективность и др.). Пресуппозиционное поле партиципантов, актуализирующее военные лозунги (Ни шагу назад!; Не отдадим завоевания Октября!; Сражайся так, чтоб не отдать ни уголка земли родной), и конструкции, обеспечивающие безопасность трудовой деятельности (Запрещается прикасаться; Отключить перед работой; Не входить), естественным образом превращают речевые формулы-запреты в шаблоны дискурсивных политических практик (обязаны, должны, виноваты, невозможно, нельзя, запрещено, не принимается, не положено и др.), а мизерное «вкрапление» языковых единиц, маркирующих истинное назначение властных структур - выполнять роль институциональных «слуг народа» (создавать условия, способствовать, помогать, уважаемый, будьте любезны, позвольте, спасибо и др.), трактуется как особый личностный признак, обусловленный воспитанием или образованием. Приведенные единицы, с нашей точки зрения, являются как показателями выработанной властной доминанты в языке, так и факторами эффективной реализации функции воздействия, подчас нарушающего экологическое пространство субъектов политической деятельности.

Причиной и одновременно следствием институциональной реверсии оказывается смещение социальных ролей, подмена понятий «право» и «обязанность» применительно к разным участникам интеракции: народ наделяется исключительно обязанностями, 
власть - одними правами. Неслучайно мы наблюдаем сегодня вербальную замену понятия «власть» понятием «владычество»: господство, превосходство, всемогущество, правление, диктатура, хозяин, корона, трон, престол и др., тогда как в языковом сознании институциональных «низов» оценка деятельности представителей власти выражается следующим образом: засилие, иго, правители, власть имущие, власти предержашие и др. Отметим, что проблема «номинация и власть» vs «власть номинации» не столько демонстрирует возможности языковой системы, сколько определяет пропозицию конструкции и вектор дальнейшего инкорпорирования знака в иные дискурсивные поля (вспомним, что еще Конфуций наставлял правителей начинать правление с изменения имен, дабы постигнуть суть вещей).

Расширение процесса институциональной реверсии в политическом пространстве вкупе с акцентуацией негативного / сокращением позитивного поля языкового сознания субъектов коммуникации и одновременным расширением референциального плана высказываний приводит к появлению новой реальности, в рамках которой формируются иные контекстуальные понятия, нормы вербального поведения, стереотипы оценок и коммуникативные традиции универсума в целом, что сближает структуру и композицию легитимных политических практик с практиками нелегитимными и даже нелегальными.

\section{Нелегитимные политические практики в аспекте эколингвистических проблем}

Нелегитимные (особенно нелегальные) политические практики представляют собой отдельную область эколингвистических исследований, которые дают полную картину использования символических возможностей языка как специфического (для человечества) способа регулирования интерактивности, межтеловой координации, позволяющей достичь результатов, недоступных для одного человеческого тела или человека [Steffensen, Fill, 2014, p. 18]. При этом цели нелегальных политических организаций лежат вне интересов отдельных индивидов, поскольку индивиды при соответствующей психологической обработке демонстрируют готовность действовать согласно планам включающей их группы и вопреки возможным личным издержкам. По характеру последствий, вызванных данным влиянием, подобные политические практики принято называть также социально «неэкологичными», наносящими вред социуму и входящим в него членам.

Оставляя в стороне темы правового регулирования, пресечения и профилактики нелегальных политических практик, обратимся к описанию того, как организуются интерактивные форматы нелегитимных политических дискурсов на примере технологий вовлечения, применяемых в деятельности радикальных организаций.

С учетом того, что под вовлечением в деятельность радикальных организаций понимается «побуждение, приобщение людей (объектов вовлечения) к (со-)участию в какой-либо, в том числе противоправной, деятельности посредством трансляции, возбуждения либо формирования в их создании специфической мотивационной установки в процессе речевого и иного воздействия субъекта (вовлекателя), осуществляемого в конкретных социальных условиях, реальном или виртуальном дискурсе» [Хазимуллина, 2016, с. 466-467], организация данного процесса может быть описана с точки зрения единства и раздельности трех составляющих неэкологичной интеракции: социокоммуникативного контекста, стадий вовлекающего воздействия, дискурсивного строя.

На уровне социокоммуникативного контекста рассмотрение вовлечения в деятельность радикальной организации связано с ответом на вопрос: «Что представляет собой вовлекатель (корпоративный субъект) как носитель определенной политической идеологии?». С описанием социокоммуникативного контекста дискурсов тесно связаны представления:

- о типе организации с точки зрения ее отношения к членству в группе (обычно такие организации являются группами инклюзивного типа - сообществами, которые решают свои задачи путем увеличения численности, регулярного обновления состава группы, организационных перестановок и т. д.); 
- ее идеологии, включающей предписания о должной пропаганде отстаиваемых политических идей;

- ее устройстве, иерархические особенности которого обусловливают степень осознанного отношения к членству в группе (как правило, новички и рядовые члены группы рассматриваются как индивиды, которые в меньшей степени посвящены в истинные цели организации, а потому подлежат опеке и направленной идеологической обработке, или «обучению»);

- ее правовом статусе, от которого зависит политическая программа сообщества и, соответственно, выбор агитационных форм (исповедование группой радикальной идеологии приводит к признанию таких организаций нелегальными, а потому влияет на выбор скрытых форм агитационной работы, вплоть до использования тайного языка для сокрытия опознавательных атрибутов);

- технологичности воспроизводимого ей процесса вовлечения, демонстрирующего продуманность и типизированность моделей склонения и удержания адептов и стейкхолдеров (внешних, невовлеченных носителей позитивного общественного мнения).

Отметим, что процесс вовлечения в деятельность радикальных организаций стадиален в силу того, что требует контроля активности аудитории и характеризуется постепенностью в приобщении вовлекаемых к цели и задачам организации. Стадии вовлекающего воздействия определяются переходом от этапа включения в сообщество к этапу самововлечения, предполагающему личную инициативу со стороны адепта. Соответственно, вовлечение, представляя собой процесс изменения состояний и установок вовлекаемых лиц, может быть описано либо с позиции взаимодействия организации с обществом как реальным и потенциальным источником единомышленников, новых адептов и стейкхолдеров, либо с точки зрения присвоения и применения объектами вовлечения идеологии организации.

В первом случае вовлечение трактуется как четырехэтапный процесс постепенного и системного приобщения ин-группой представителей аут-группы: образование сообщества; совместное совершение какой-либо деятельности членами ин-группы, имеющими разную степень приобщенности; созидание об- раза организации вместе с лояльно настроенными членами аут-группы (например, стейкхолдерами, родственниками, правозащитниками, авторитетами религиозных общин и др.); выход на более широкую аудиторию, в том числе путем использования дигитальных форматов публичности [Araeva et al., 2018, p. 142].

Во втором случае вовлечение описывается как последовательность состояний, характеризующих степень инкорпорированности объектов (субъектов) в деятельность радикальных организаций, - от состояний заинтересованности, вызываемых стимулирующими аттракциями, до полного погружения в деятельность ингруппы [Хазимуллина, 2016, с. 463].

Как отмечается в работах ученых (см., например: [Фомина, 2016; Хазимуллина, 2016; Araeva et al., 2018]), на каждом этапе вовлечения обнаруживаются:

- специфические намерения вовлекателя, связанные с попытками формирования благоприятного коммуникативного фона, неявным изучением кандидатуры на возможность ее работы в организации, удержанием внимания кандидата на желательных для группы ценностях, задачах, ритуалах и т. д.;

- типичные стратегические линии речевого поведения вовлекателя, чья императивность, эксплицитность и категоричность проявляются все больше по мере включения адепта в ин-группу;

- характерное реактивное поведение, свидетельствующее о вовлеченности / невовлеченности объекта (ср. возможные реакции вовлеченности: согласие, запрос дополнительной информации, отчет о проделанной работе, участие в планировании мероприятий и т. д.);

- особые жанры вовлечения (обучающие мероприятия, дружеские встречи с целью расположения первичной аудитории, прокламации, книги идеологической направленности, молитвы и т. д.).

Важнейшими показателями вовлеченности в деятельность радикально настроенных групп являются маркеры: мелиоративной оценки «своих» и, напротив, пейоративной «чужих»; готовности к выполнению чего-либо противозаконного, сокрытию его и маскировке; инклюзивности, кооперативности, самоидентификации (инклюзивные глаголы: $n p u$ гласить кого-л., приводить кого-л. куда-л., 
делать вместе что-л. и др.; местоимения: мbl, наш и др.; выражения с семантикой общности, объединения, вхождения (включения) в группу: вместе с (нами), с теми, (кто) я, совместно и др.; самоназвания, как шуточные, так и маскирующие); коммуникативной активности (например, активного и рефлексивного слушания); регулярности выполнения ритуальных действий (присутствия на мероприятиях, посещения их и т. д.); близости к внутрисловному контексту (например, использование жаргонных элементов, не вызывающих трудностей при восприятии сообщения; пропозиций, вводящих сведения о событиях и обстоятельствах, связанных с жизнедеятельностью организации; информационных поводов, относительно которых формулируются реплики общающихся и т. д.).

Дискурсивное поведение вовлекателя состоит в том, что он проводит обучающие и иные занятия, использует специальные обращения с целью усиления апеллятивной и контактоустанавливающей функций, активизирует и направляет деятельность вовлекаемых, доминирует в диалогах, настойчиво проводит ключевые идеи, разъясняет необходимые положения, дает оценку, советы, директивные указания, осуществляет контроль за восприятием и пониманием информации, получаемой участниками, убеждает участников группы в необходимости выполнения призывных действий, сообщает о решениях вышестоящего руководства, информирует о предстоящих делах, руководит планированием совместной деятельности, мотивирует вовлекаемых, следит за активностью подчиненных, может позволить себе критику, перебивы, повышенную тональность в отношении подопечных.

Дискурсивное поведение вовлекаемых заключается в том, что они соблюдают субординацию по отношению к коммуникативному лидеру, склонны соглашаться с субъектом вовлечения; объем и развернутость их реплик варьирует в зависимости от этапа вовлечения; они дают ответы на поставленные лидером вопросы, спрашивают разрешения для того, чтобы активно участвовать в разговоре, интерпретируют происходящее под углом зрения лидера, советуются с ним, отчитываются перед ним, демонстрируют позитивный настрой на восприятие информации, выполняют домашние задания, стремятся лучше разобраться в обсуждаемых вопросах, готовят отчет о работе, принимают и соблюдают нормы взаимодействия в группе.

Следовательно, описание дискурсивного строя вовлекающих практик осуществляется в ходе рассмотрения и оценки выбора их участниками фактур общения (устной / письменной / цифровой, непосредственной / опосредованной, реальной / виртуальной коммуникации) > жанровых форм > средств их реализации. При этом коммуникативно-семиотические механизмы кодирования интенции вовлечения демонстрируют такую иерархическую организацию актов общения, за счет которой речевые стратегии вовлекателя и вовлекаемого обеспечиваются совокупностью конститутивных элементов: пассажами, текстовыми макростратегиями, локальными речевыми актами, локальными значениями и передающими их лексическими единицами, грамматическими формами и средствами локального синтаксиса.

Соответствие показателей реализации установки на вовлечение и состояний погруженности в искомый социокоммуникативный контекст этапам наводимого психосемиотического воздействия свидетельствует о глубине адаптации символической системы к условиям определенных неэкологичных политических практик, а также об уровне «интоксикации» сознания, вызванной воздействием на индивидов рассматриваемой социальной среды.

\section{Заключение}

Слово есть феномен, претерпевающий бесконечное развитие и подвергающийся таким же непрестанным исследованиям: язык как базисный атрибут человека, выделяющий его из всей экосистемы, является самым ярким маркером взаимоотношений объекта и среды и, соответственно, «должен сохранять все признаки человечности» [Бернацкая, 2014, с. 28 ]. Однако процессы многовекового бытования вербальных знаков демонстрируют расширение семасиологической емкости слова, поскольку дискурсивные практики находятся в состоянии взаимопроникновения и взаимодополнения, детерминированных мыслительными, поведенческими, этнокультурными компонента- 
ми социальных отношений. В этой связи политический дискурс как отдельное пространственно-временное образование и вместе с тем системное явление, эксплицирующее многомерный лингвоментальный материал, оказывается наиболее «чувствительным» к различного рода трансформациям, что обусловливает «токсичность» политического пространства и тем самым нарушение лингвоэкосистемы.

Производные значения знаковых единиц, порождаемые в результате использования определенных стратегий, тактик, вербализованных и «семасиологически скрытых» способов эксплицирования / вуалирования интенций партиципантов, развиваются на основе вербально-семиотических ассоциаций и формируют сложнейшую по структуре текстовую / дискурсивную единицу, имеющую «многопластовый» семантический «заряд» и высочайший экспрессивно-эмоциональный потенциал. Таким образом, политическая логосфера как часть экосистемы - это не столько продукт деятельности общества, сколько его генератор: «пронизывая» все пласты общечеловеческой логосферы, она активно формирует правила коммуникативных интеракций включенных в нее субъектов, их социально-иерархическую структуру и лингвоэтнический универсум в целом.

\section{ПРИМЕЧАНИЯ}

${ }^{1}$ Статья выполнена в рамках гранта РФФИ № 18-012-00574 «Лингвокультурные доминанты легитимных / нелегитимных политических дискурсивных практик в пространстве русскоязычной коммуникации: типологическое исследование».

The reported study was funded by RFBR, grant number 18-012-00574 "Linguistic and Cultural Dominants of Legitimate and Illegitimate Political Discursive Practices in Russian-Language Communication: A Typological Research".

${ }^{2}$ Отметим комментарий А.П. Сковородникова: «Представляется, что травма языку может быть нанесена только в том случае, если травмировано сознание народа, говорящего на этом языке» [Сковородников, 2013, с. 208].

${ }^{3}$ В ряде случаев, бесспорно, исключение жаргонной лексики из репертуара публицистической / разговорной речи нецелесообразно, так как ее экспрессию и «экономную точность» невозможно восполнить другими средствами.
${ }^{4}$ Например, употребление онимов - географических названий (с закреплением в законодательных актах!) в формах, чуждых грамматической системе русского языка: Республика Беларусь с соединительным $a$ вместо $o$; Молдова с усечением -ия и др.

${ }^{5}$ Иллюстрацией тезиса могут послужить стилизованные под фольклор тексты, активно использующиеся в предвыборных кампаниях: Милый мой рычит, как лев, / Он теперь в КПРФ. / Что же он не в духе? / Там одни старухи. Здесь в форме народной частушки реализованы как минимум две важные функции политического дискурса - агональная и развлекательная.

${ }^{6}$ Неделя хороших новостей, объявленная в России в период проведения чемпионата мира по футболу, стала скорее исключением из правил.

7 По мнению многих ученых, Родина не просто концепт, идеологема или константа русской культуры: сила воздействия и укорененность (а потому непереводимость) этого слова в сознании носителей русского языка настолько велика, что данный знак рассматривают как «риторическую машину, механика которой настроена на производство дискурсивных практик» [Сандомирская, 2001, S. 3].

${ }^{8}$ Персеверация является неотъемлемым элементом различных суггестивных и театрализованных дискурсов - от рекламного до религиозного.

\section{СПИСОК ЛИТЕРАТУРЫ}

Бернацкая А. А., 2014. Лингвоэкология и «критика языка» // Экология языка и коммуникативная практика. № 2. С. 15-31.

Демьянков В. 3., 2001. Интерпретация политического дискурса в СМИ // Язык СМИ как объект междициплинарного исследования. М. : Изд-во МГУ. С. 116-133.

Завершинский К. Ф., 2016. Легитимация политической власти: морфология научного дискурса // ПОЛИТЭКС. Т. 12, № 4. С. 4-18.

Ионова С. В., Шаховский В. И., 2012. Человек и его языковая среда: эколингвистический аспект // Антропология языка = The Antropology of Language : сб. ст. / отв. ред. С. Р. Омельченко. М. : Флинта : Наука. Вып. 2. С. 137-148.

Карасик В. И., 2007. Языковые ключи. Волгоград : Парадигма. $520 \mathrm{c.}$

Лотман Ю. М., 2010. Непредсказуемые механизмы культуры. Таллинн : TLU Press. 232 c.

Николаева Т. М., 1990. О принципе «некооперации» и/или о категориях социолингвистического воздействия // Логический анализ языка. Противоречивость и аномальность текста : сб. ст. / под ред. Н. Д. Арутюновой. М. : Наука. С. 225-226. 
Паршин П. Б., 2001. Исследовательские практики, предмет и методы политической лингвистики // Проблемы прикладной лингвистики = Scripta linguisticae applicatae : сб. ст. / отв. ред. Н. В. Васильева. М. : Азбуковник. С. 181-207.

Паршина О. Н., 2004. Стратегии и тактики речевого поведения современной политической элиты России : монография. Астрахань : Изд-во АГТУ. 195 с.

Русакова О. Ф., Русаков В. М., 2008. РR-дискурс: теоретико-методологический анализ. Екатеринбург : УрО РАН : Ин-т междунар. связей. 282 с.

Сандомирская И., 2001. Книга о родине : Опыт анализа дискурсивных практик. Wien : Gesellschaft zur Förderung slawistischer Studien. 282 S. (Wiener slawistischer Almanach ; Sonderband 50).

Сковородников А. П., 2013. О предмете эколингвистики применительно к состоянию современного русского языка // Экология языка и коммуникативная практика. № 1. С. 205-233.

Фомина Ю. С., 2016. Особенности реализации речевых актов побуждения в текстах экстремистской направленности // Acta linguistica petropolitana. Труды Института лингвистических исследований РАН. Т. ХІІ, ч. 3. C. 441-451.

Хазимуллина Е. Е., 2016. Механизм речевого вовлечения в деятельность экстремистских организаций // Acta linguistica petropolitana. Труды Института лингвистических исследований PAH. T. XII, ч. 3. С. 453-469.

Шейгал Е. И., 2000. Семиотика политического дискурса. Волгоград : Перемена. 386 с.

Юрислингвистика-7 : Язык как феномен правовой коммуникации : межвуз. сб. науч. тр., 2006 / под ред. Н. Д. Голева. Барнаул : Изд-во Алт. ун-та. 348 с.

Araeva L. A., Katyshev P. A., Osadchiy M. A., Olenev S. V., 2018. Recontextualization of the Religious Term 'Ziyarat': Critical Discourse Study // European Journal of Science and Theology. Vol. 14, № 5. P. 137-147.

Graber D., 1981. Political Languages // Handbook of Political Communication. Beverly Hills ; L. : Sage Publications. P. 195-224.

Steffensen S. V., Fill A., 2014. Ecolinguistics: The state of the art and future horizons // Language Sciences. Vol. 41A. P. 6-25. DOI: 10.1016/j.langsci. 2013.08.003.

\section{REFERENCES}

Bernatskaya A.A., 2014. Lingvoekologiya i «kritika yazyka» [Linguistic Ecology and "Language
Criticism"]. Ekologiya yazyka $i$ kommunikativnaya praktika [Ecology of Language and Communicative Practice], no. 2, pp. 15-31.

Demyankov V.Z., 2001. Interpretatsiya politicheskogo diskursa v SMI [Interpretation of Political Discourse in Mass Media]. Yazyk SMI kak obyekt mezhdistsiplinarnogo issledovaniya [Language of Mass Media as an Object of Interdisciplinary Research]. Moscow, Izd-vo MGU, pp. 116-133.

Zavershinskiy K.F., 2016. Legitimatsiya politicheskoy vlasti: morfologiya nauchnogo diskursa [Legitimation of Political Power: Morphology of Scientific Discurse]. POLITEKS, vol. 12, no. 4, pp. 4-18.

Ionova S.V., Shakhovskiy V.I., 2012. Chelovek i yego yazykovaya sreda: ekolingvisticheskiy aspekt [Person and Lingual Environment: An Ecolinguistic Aspect]. Omelchenko S.R., ed. Antropologiya yazyka = The Antropology of Language: sb. st. [The Antropology of Language. Collected Articles]. Moscow, Flinta Publ., Nauka Publ., iss. 2, pp. 137-148.

Karasik V.I., 2007. Yazykovye klyuchi [Language Keys]. Volgograd, Paradigma Publ. 520 p.

Lotman Yu.M., 2010. Nepredskazuemye mekhanizmy kultury [Unpredictable Mechanisms of Culture]. Tallinn, TLU Press. 232 p.

Nikolaeva T.M., 1990. O printsipe «nekooperatsii» i/ili o kategoriyakh sotsiolingvisticheskogo vozdeystviya [On the Principle of "NonCooperation" and/or on the Categories of Sociolinguistic Impact]. Arutyunova N.D., ed. Logicheskiy analiz yazyka. Protivorechivost $i$ anomalnost teksta: sb. st. [Logical Analysis of Language. The Contradictory and Anomalous Text. Collected Articles]. Moscow, Nauka Publ., pp. 225-226.

Parshin P.B., 2001. Issledovatelskie praktiki, predmet i metody politicheskoy lingvistiki [Research Practices, Subject and Methods of Political Linguistics]. Vasilyeva N.V., ed. Problemy prikladnoy lingvistiki = Scripta linguisticae applicatae: $s b$. st. $[$ Problems of Applied Linguistics $=$ Scripta Linguisticae Applicatae. Collected Articles]. Moscow, Azbukovnik Publ., pp. 181-207.

Parshina O.N., 2004. Strategii $i$ taktiki rechevogo povedeniya sovremennoy politicheskoy elity Rossii: monografiya [Strategies and Tactics of Speech Behavior of the Modern Political Elite of Russia. Monograph]. Astrakhan, Izd-vo AGTU. $195 \mathrm{p}$.

Rusakova O.F., Rusakov V.M., 2008. PR-Diskurs: teoretiko-metodologicheskiy analiz [PRDiscourse: Theoretical and Methodological 
Analysis]. Yekaterinburg, UrO RAN, Institut mezhdunarodnykh svyazey. $282 \mathrm{p}$.

Sandomirskaya I., 2001. Kniga o rodine: opyt analiza diskursivnykh praktik [A Book About the Homeland: The Experience of Analyzing Discourse Practices]. Wien, Gesellschaft zur Förderung slawistischer Studien. 282 p. (Wiener slawistischer Almanach; Sonderband 50).

Skovorodnikov A.P., 2013. O predmete ekolingvistiki primenitelno $\mathrm{k}$ sostoyaniyu sovremennogo russkogo yazyka [On the Way of Ecolinguistics Can Be Applied to the State of Contemporary Russian Language]. Ekologiya yazyka i kommunikativnaya praktika [Ecology of Language and Communicative Practice], no. 1, pp. 205-233.

Fomina Yu.S., 2016. Osobennosti realizatsii rechevykh aktov pobuzhdeniya $\mathrm{v}$ tekstakh ekstremistskoy napravlennosti [Features of Verbal Acts of Motivation in Extremist Texts]. Acta linguistica petropolitana. Trudy Instituta lingvisticheskikh issledovaniy RAN [Acta Linguistica Petropolitana], vol. 12, part 3, pp. 441-451.

KhazimullinaE.E.,2016. Mekhanizmrechevogovovlecheniya v deyatelnost ekstremistskikh organizatsiy [Mechanism of Speech Involvement by Extremist
Organisations]. Trudy Instituta lingvisticheskikh issledovaniy RAN[Acta Linguistica Petropolitana], vol. 12, part3, pp. 453-469.

Sheygal E.I., 2000. Semiotika politicheskogo diskursa [Semiotics of Political Discourse]. Volgograd, Peremena Publ. 386 p.

Golev N.D., ed., 2006. Yurislingvistika-7: Yazyk kak fenomen pravovoy kommunikatsii: mezhvuz. sb. nauch. tr. [Legal Linguistics-7: Language as a Phenomenon of Legal Communication: Inter-University Collection of Scientific Papers]. Barnaul, Izd-vo Altayskogo universiteta. 348 p.

Araeva L.A., Katyshev P.A., Osadchiy M.A., Olenev S.V., 2018. Recontextualization of the Religious Term 'Ziyarat': Critical Discourse Study. European Journal of Science and Theology, vol. 14, no. 5, pp. 137-147.

Graber D., 1981. Political Languages. Handbook of Political Communication. Beverly Hills, London, Sage Publications, pp. 195-224.

Steffensen S.V., Fill A., 2014. Ecolinguistics: The State of the Art and Future Horizons. Language Sciences, vol. 41A, pp. 6-25. DOI: 10.1016/ j.langsci.2013.08.003.

\section{Information about the Authors}

Natalya A. Bozhenkova, Doctor of Sciences (Philology), Professor, Department of General and Russian Linguistics, Pushkin State Russian Language Institute, Akademika Volgina St., 6, 117485 Moscow, Russia, natalyach@mail.ru, https://orcid.org/0000-0002-2381-5865

Pavel A. Katyshev, Doctor of Sciences (Philology), Professor, Department of General and Russian Linguistics, Pushkin State Russian Language Institute, Akademika Volgina St., 6, 117485 Moscow, Russia, katpa@rambler.ru,https://orcid.org/0000-0002-2492-6495

Svetlana V. Ionova, Doctor of Sciences (Philology), Professor, Department of General and Russian Linguistics, Pushkin State Russian Language Institute, Akademika Volgina St., 6, 117485 Moscow, Russia, sionova@mail.ru,https://orcid.org/0000-0001-6361-741X

Elmira M. Afanasyeva, Doctor of Sciences (Philology), Chief Researcher, Project Scientific and Research Laboratory of Innovative Means in Russian Language Teaching, Pushkin State Russian Language Institute, Akademika Volgina St., 6, 117485 Moscow, Russia, elmira_afanaseva@mail.ru, https://orcid.org/0000-0003-1544-4715

Levon N. Saakyan, Candidate of Sciences (Philology), Associate Professor, Department of General and Russian Linguistics, Pushkin State Russian Language Institute, Akademika Volgina St., 6, 117485 Moscow, Russia, sahalev@mail.ru, https://orcid.org/0000-0002-5046-7894

\section{Информация об авторах}

Наталья Александровна Боженкова, доктор филологических наук, профессор кафедры общего и русского языкознания, Государственный институт русского языка им. А.С. Пушкина, ул. Академика Волгина, 6, 117485 г. Москва, Россия, natalyach@mail.ru, https://orcid.org/0000-0002-2381-5865

Павел Алексеевич Катышев, доктор филологических наук, профессор кафедры общего и русского языкознания, Государственный институт русского языка им. А.С. Пушкина, ул. Академика Волгина, 6, 117485 г. Москва, Россия, katpa@rambler.ru, https://orcid.org/0000-0002-2492-6495 


\section{ГЛАВНАЯ ТЕМА НОМЕРА}

Светлана Валентиновна Ионова, доктор филологических наук, профессор кафедры общего и русского языкознания, Государственный институт русского языка им. А.С. Пушкина, ул. Академика Волгина, 6, 117485 г. Москва, Россия, sionova@mail.ru, https://orcid.org/0000-0001-6361-741X

Эльмира Маратовна Афанасьева, доктор филологических наук, главный научный сотрудник проектной научно-исследовательской лаборатории инновационных средств обучения русскому языку, Государственный институт русского языка им. А.С. Пушкина, ул. Академика Волгина, 6, 117485 г. Москва, Россия, elmira_afanaseva@mail.ru, https://orcid.org/0000-0003-1544-4715

Левон Николаевич Саакян, кандидат филологических наук, доцент кафедры общего и русского языкознания, Государственный институт русского языка им. А.С. Пушкина, ул. Академика Волгина, 6, 117485 г. Москва, Россия, sahalev@mail.ru, https://orcid.org/0000-0002-5046-7894 